\title{
Chemistry Teacher's Perception About Their Technology, Pedagogical, and Content Knowledge (TPACK)
}

\author{
Sonya Monica Liunokas ${ }^{1, *}$ Isana Supiah Yosephine Louise ${ }^{2,}$ Falenthino \\ Sampouw $^{3}$
}

\author{
${ }^{1}$ Master of Chemistry Education, Faculty of Mathematics and Natural Sciences, Universitas Negeri Yogyakarta, \\ Indonesia \\ ${ }^{2}$ Department of Chemistry Education, Faculty of Mathematics and Natural Sciences, Universitas Negeri \\ Yogyakarta, Indonesia \\ ${ }^{3}$ Master of Mathematics Education, Faculty of Mathematics and Natural Sciences, Universitas Negeri \\ Yogyakarta, Indonesia \\ ${ }^{*}$ Corresponding author. Email: sonya0056pasca.2019@student.un.ac.id
}

\begin{abstract}
Education is currently facing the challenges of 21 st-century learning. Moreover, covid-19 pandemic has caused all face-to-face learning activities in schools to be replaced with online learning. This phenomenon requires teachers to understand and have competency in technological, pedagogical and content knowledge (TPACK). The aim of this research is to describe the perceptions of TPACK high school chemistry teachers. This research was conducted on 32 chemistry teachers in the province of East Nusa Tenggara using the TPACK questionnaire instrument with seven components. TPACK perception data were analyzed using a descriptive quantitative approach, while the difference in teacher TPACK based on gender and teaching experience was analyzed using the Mann-Whitney U test with SPSS.25 because the sample was small. In accordance with the data analysis carried out states that the chemistry teacher's perception of TPACK is in the "good" category in general and the highest average score is in the PK component. The components that have a strong positive correlation are PK, TPK, TCK, and TPCK which have a significant effect on the perception of TPACK for SMA chemistry teachers. Also, based on gender and teaching experience did not have a significant effect on TPACK perception.
\end{abstract}

Keywords: TPACK, Gender, Teaching experience.

\section{INTRODUCTION}

Education is currently facing the challenges of 21 st-century learning. The $21 \mathrm{st}$ - century learning paradigm requires students to have thinking and learning skills, including problem-solving skills, critical thinking, communication skills, creativity, collaboration, and mastery of science and technology. Moreover, with the covid-19 pandemic, all face-toface learning activities in schools have been replaced with online learning. This requires teachers to be extra in preparing for the teaching and learning process.

Teaching is a dinamic activity that requires a variety of specific knowledge and skills from a teacher. Teaching activities involve aspects of the personal quality and competence of the teacher himself [1]. Teacher competence is very important in the teaching and learning process. Based on Government Regulation Number 18 of 2017 concerning teachers, the competencies that teachers must possess include pedagogical competence, personality competence, social competence, and professional competence. Of all competencies, pedagogical competence is the most important thing that must be mastered by a teacher during learning. Pedagogic competence is the teacher's ability to carry out the learning process. However, pedagogical competence cannot be separated from mastery of the material (content) because it is mutually sustainable, thus forming the concept of PCK (Pedagogical 
Content Knowledge) [2]. A teacher does not only master the material and concept but must master how teaching and learning strategies can be conveyed to students properly. Besides, teachers are required to utilize technology in the process of learning, in line with the initiation of 21st-century learning. Several studies [3], [4], [5] reveal that teachers have difficulty integrating technology or software programs, especially in deciding which tools are the most appropriate to teach good and make student want to learn. Also, teachers sometimes cannot integrate technology with good in teaching and learning process due to a lack of pedagogical knowledge [6]. 21st century learning is characterized by the effective use of information and communication technology that can make students work collaboratively and solve problems [7].

In the context of learning chemistry, the difficulties experienced by students in understanding chemistry are due to chemical material which consists of abstract and complex concepts [8]. Chemical materials that are abstract and complex make chemistry learning difficult for students to understand [9]. Then, [10] stated that one of the important characters of the chemical matter is the existence of a unity that interplay between the macroscopic and microscopic levels in material content. So that this is a challenge for students and educators in understanding and teaching chemistry. Educational technology such as video, animation and simulation can help in to describing learning material [11]. Chemistry teachers who incorporate educational technology into learning can build the creation of innovative learning [12].

The description above illustrates that technology can help teachers teach chemical concepts. This results in the development of teacher knowledge. Teachers do not only have pedagogical and content knowledge, but also technological knowledge that can be integrated into chemistry learning. The teacher's knowledge framework that involves TPC is known as technological pedagogical and content knowledge [13], [14], [15]. The TPACK shows that content knowledge that is integrated into technology and pedagogical skills are an important condition in creating effective and innovative classroom teaching using technology. TPACK is a sound teaching foundation with technology and needs an understanding of conceptual representation with technology, pedagogical ability that use technology in a constructively way to interpret the material, knowledge of what makes concepts difficult or easy to know, and in various ways technology can help fix something problems faced by students in learning [16], [17], [18]. Therefore, along with the development of 21 st-century skills, we need to know the abilities of teachers through descriptions of TPACK

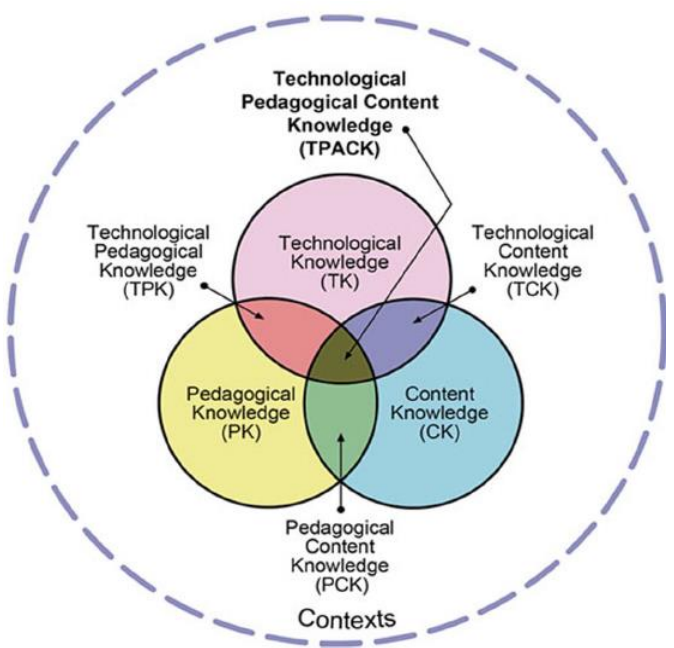

Figure 17 Components of TPACK

In Figure 1, it is clear that TPACK consists of three knowledge domains, namely technological knowledge, pedagogy, and content. Besides, there are interactions from each domain, namely technology and pedagogy, technology and content, and pedagogy and content. The three domains also interact with each other and form the TPCK. Thus there are 7 components of TPACK. Each component describes the knowledge that teachers must have in creating effective and innovative learning.

The rapid development of 21st -century technology and can be integrated into classroom learning has made technology one of the domains of knowledge that teachers are must-have. Thus the teacher does not only think about the pedagogy and chemical content taught in the classroom, but also how to apply technology so that effective and efficient learning can be realized to achieve the set learning objectives. Therefore, it is necessary to have an understanding of how teachers perceive their knowledge. TPACK is a knowledge framework that combines technology, pedagogy, and content which is deemed appropriate to assess teachers' perceptions of their knowledge. 
Table 1. Descriptions of components in TPACK

\begin{tabular}{|c|l|}
\hline Components & \multicolumn{1}{c|}{ Description } \\
\hline TK & $\begin{array}{l}\text { The knowledge and skills that include technological knowledge, in this case information } \\
\text { processing, communication and problem solving using technology. }\end{array}$ \\
\hline CK & $\begin{array}{l}\text { The knowledge that must be possessed by a teacher regarding the theory and concept of a } \\
\text { subject matter that will be taught to students. }\end{array}$ \\
\hline PK & $\begin{array}{l}\text { A collection of knowledge about teaching and learning in this case is closely related to learning } \\
\text { methods, classroom management, learning design, student assessment, etc. }\end{array}$ \\
\hline TCK & Information on the connection between the topic and the innovation used in learning. \\
\hline TPK & The information on how innovation from a technology can be applied in learning activities. \\
\hline PCK & The combination of learning materials with pedagogical knowledge. \\
\hline TPCK & The blending of undestanding of content, pedagogy and technology. \\
\hline
\end{tabular}

\section{RESEARCH METHODS}

This research uses a descriptive quantitative approach to describe the chemistry teachers' perceptions of their knowledge seen from TPACK framework. Respondents in this study were 32 chemistry teachers in East Nusa Tenggara Province (10 male and 22 female). The sample selection was done by using the purposive sampling technique. The data collection process was carried out online using a google form containing a TPACK questionnaire and distributed through the Whatsaap group to chemistry teachers as respondents. Analysis of teacher perceptions of TPACK using the TPACK questionnaire. Overall the questionnaire consisted of 45 statement items covering the 7 TPACK subdomains. Details of the distribution of statement items, namely 6 TK items, 16 PK items, 2 CK items, 6 TPK items, 2 TCK items, 9 PCK items, and 4 TPCK items. The instrument uses 5 Likert scales consisting of; 1) strongly disagree; 2) disagree; 3) hesitated; 4) agree, and 5) strongly agree. All instrument items have been tested for validity and reliability. The validity test used the pearson product moment correlation with all valid results. While reliability was tested using cronbach's alpha with a result of 0.933 . Meanwhile, the analysis used to determine whether there is a different in the TPACK of teachers based on gender and teaching experience is the Mann Whitney U test with SPSS.25 because the sample small.

\section{RESULT AND DISCUSSION}

\subsection{Chemistry Teacher's Perception of TPACK}

In this research, the identification and description of the TPACK Chemistry teachers perceptions on the
TPACK framework was conducted. The results of this study can be shown in table 2 .

Table 2. Results of descriptive statistics for all components

\begin{tabular}{|l|c|c|c|}
\hline $\begin{array}{c}\text { Components of } \\
\text { TPACK }\end{array}$ & Mean & $\begin{array}{c}\text { Standard } \\
\text { Deviation }\end{array}$ & Category \\
\hline TK & 3.79 & 0.901 & Good \\
\hline PK & 4.035 & 0.667 & Good \\
\hline CK & 3.89 & 0.758 & Good \\
\hline TPK & 3.985 & 0.536 & Good \\
\hline TCK & 3.875 & 0.454 & Good \\
\hline PCK & 3.96 & 0.558 & Good \\
\hline TPCK & 3.95 & 0.544 & Good \\
\hline
\end{tabular}

As shown in the table and using a likert scale category is seen that the value of the mean for all the components with the most number of "agree" options on the scale. This score also means that the chemistry teacher feels that he or she has a "good" TPACK level in general. It can also be seen that chemistry teachers in East Nusa Tenggara have the highest total average in the PK component of 4.035, meaning that chemistry teachers have a good understanding of how to learn and carry out learning in the classroom which includes everything related to planning, process, and evaluation learning. Meanwhile, for the other components, namely TPK, PCK, TPCK, TCK and TK respectively the average value was $3.985 ; 3.96 ; 3.95 ; 3.89 ; 3.875$ and 3.79 .

TPACK development depends on many factors, including experience in using the right technology in the learning process [19]. TPACK improvement also relies on the learning environment to increase competence in integrating technology [20], [21], [22]. 
Therefore, the overall level of understanding of the TPACK Chemistry teacher still needs to be improved to produce integrated and effective technology, pedagogy, and learning content.

It is indicated that there is a result relationship between TPACK components. This is known from the correlation analysis formed between TPACK components can shown in Figure 2, at a significant level of 0.05 . There is a strong positive correlation, namely PK is correlated with PCK $(r=0.602)$, TCK $(r$ $=0.620)$, PCK $(r=0.650)$, TPCK $(r=0.514)$, CK is correlated with PCK $(\mathrm{r}=0.675)$, PCK is correlated with TPCK $(r=0,529)$, TCK correlated with TPCK $(r$ $=0.559)$, TPK correlated with TCK $(\mathrm{r}=0.521)$, TPK correlated with PCK $(\mathrm{r}=0.545)$, and TPCK $(\mathrm{r}=$ 0.644). While anassociation of positive correlation moderate namely TK correlated with PK $(\mathrm{r}=0.381)$, CK $(r=0.386)$, and TPK $(r=0.473)$, PK correlated with CK (0.487), CK correlated with TCK ( 0.367), TPK $(r=0.223)$, and TPCK $(r=0.260)$, TCK correlates with PCK (0.434), TK correlates with TCK $(\mathrm{r}=0.230)$. Meanwhile, others have a weak correlation.

Thus in this study, the components that had the most significant influence on the development of TPACK in chemistry teachers were PK, TPK, TCK, and TPCK. This is in line with research [23] where PK is the most influential component. The results of this study are also in line with the results of research conducted [24], where the connection between TPK and TPCK, and TCK and TPCK has a significant connection.

Based on the research results, it can be said that the development of TPACK cannot be seen separately from PK, CK, and TK. [25] stated that understanding of TPACK differs from CK, PK and TK when understood separately. Therefore, the development of TPACK for teachers should be done ceaselessly and not separately but in a unity.

\begin{tabular}{|c|c|c|c|c|c|c|c|c|}
\hline \multicolumn{9}{|c|}{ Correlations } \\
\hline & & TK & $\mathrm{PK}$ & $\mathrm{CK}$ & TPK & TCK & $\mathrm{PCK}$ & TPCK \\
\hline \multirow{3}{*}{ TK } & Pesrson Correlation & 1 & $456^{-5}$ & $387^{*}$ &, $506^{-4}$ &, 270 &, $376^{\circ}$ &, $359^{*}$ \\
\hline & Sig. (2-tailed) & &, 009 & 029 &, 003 &, 135 &, 034 &, 044 \\
\hline & $\mathrm{N}$ & & 32 & 32 & 32 & 32 & 32 & 32 \\
\hline \multirow{3}{*}{$\mathrm{PK}$} & Pearson Correlation & & 1 & $464^{-}$ &, $546^{-}$ &, $563^{-}$ &, $523^{-}$ & $466^{-1}$ \\
\hline & Sig. (2-tsiled) & & &, 008 &, 001 &, 001 &, 002 &, 007 \\
\hline & $\mathrm{N}$ & & & 32 & 32 & 32 & 32 & 32 \\
\hline \multirow[t]{3}{*}{$\mathrm{CK}$} & Pearson Correlation & & & 1 & 075 & 313 &, $511^{-}$ & 213 \\
\hline & Sig. (2-tailed) & & & &, 682 &, 081 &, 003 & ,241 \\
\hline & $\mathrm{N}$ & & & & 32 & 32 & 32 & 32 \\
\hline \multirow{3}{*}{ TPK } & Pearson Correlation & & & & 1 &, $444^{*}$ &, $425^{\circ}$ &, $612^{-1}$ \\
\hline & Sig. (2-tsiled) & & & & &, 011 &, 015 &, 000 \\
\hline & $N$ & & & & & 32 & 32 & 32 \\
\hline \multirow{3}{*}{ TCK } & Pearson Correlation & & & & & 1 & 323 & $467^{-1}$ \\
\hline & Sig. (2-tailed) & & & & & &, 071 &, 007 \\
\hline & $\mathrm{N}$ & & & & & & 32 & 32 \\
\hline \multirow[t]{3}{*}{$\mathrm{PCK}$} & Pegrson Correlation & & & & & & 1 & $517^{-1}$ \\
\hline & Sig. (2-tailed) & & & & & & &, 002 \\
\hline & $N$ & & & & & & & 32 \\
\hline \multirow[t]{3}{*}{ TPCK } & Pearson Correlation & & & & & & & 1 \\
\hline & Sig. (2-tailed) & & & & & & & \\
\hline & $\mathrm{N}$ & & & & & & & \\
\hline \multicolumn{9}{|c|}{-. Correlstion is significant at the 0.01 level (2-tailed). } \\
\hline \multicolumn{9}{|c|}{$\because$ Correlation is significant at the 0.05 level (2-tailed). } \\
\hline
\end{tabular}

Figure 2 Correlation results between TPACK components

\subsection{Chemistry Teacher's Perception of TPACK by Gender}

Teacher's TPACK perceptions of 7 components by gender were analyzed using the Mann Whitney U test with SPSS.25. Table 3 show the results of the analysis. The results seems that there is no significant difference in gender on the components of TK, PK, CK, TCK, PCK, TPK, and TPCK. This result is by following under the research that in the development of TPACK between male and female teachers there is no significant difference [26]. Other studies have also stated that there is no significant impact of gender on TPACK [27]. 
Table 3. Descriptive statistics of TPACK in terms of gender

\begin{tabular}{|l|c|c|c|c|c|c|c|}
\hline \multirow{2}{*}{ Components } & \multicolumn{2}{|c|}{ Male } & \multicolumn{2}{c|}{ Female } & \multicolumn{2}{|c|}{ Result } \\
\cline { 2 - 8 } & $\begin{array}{c}\text { Mean } \\
\text { Rank }\end{array}$ & $\begin{array}{c}\text { Sum of } \\
\text { Ranks }\end{array}$ & Mean Rank & $\begin{array}{c}\text { Sum of } \\
\text { Ranks }\end{array}$ & $U$ & $P$ & No diference \\
\hline TK & 20.55 & 205.50 & 14.66 & 322.50 & 69.50 & 0.098 & No diference \\
\hline PK & 14.70 & 147.00 & 17.32 & 381.00 & 92.00 & 0.463 & No diference \\
\hline CK & 17.00 & 170.00 & 16.27 & 358.00 & 105.00 & 0.829 & No diference \\
\hline TPK & 18.60 & 186,00 & 15.55 & 342.00 & 89.00 & 0.367 & No diference \\
\hline TCK & 16.15 & 161.50 & 16.66 & 366.50 & 106.50 & 0.869 & No diference \\
\hline PCK & 16.85 & 168.50 & 16.34 & 359.50 & 106.50 & 0.886 & No diference \\
\hline TPCK & 16.05 & 160.50 & 16.70 & 367.50 & 105.50 & 0.845 & \\
\hline
\end{tabular}

\subsection{Perceptions of TPACK Based On the Experience of Teaching}

Teachers' perceptions of TPACK can also be seen from the teacher's teaching experience. The results of the analysis using Mann Whitney $U$ test according to SPSS.25 were carried out to compare teachers' TPACK perceptions of 7 components can be seen in table 4 . The results showed that teachers who have teaching experience more than equals 3 years and less than 3 years did not have a significant difference in the perception of TPACK. Similar research also states that teaching experience does not affect TPACK perceptions [28]. Another study said that expert teachers have a high level of experience and professionalism compared to new teachers who tend to be less confident with their abilities and understanding that have just been formed in a short time in teaching [29]. In other words, the more years a teacher has taught, the teacher's knowledge and skills in planning, implementing, managing, and evaluating teaching and learning activities will also increase.

Table 4. Descriptive statistics for total scores of TPACK in terms of the experience of teaching

\begin{tabular}{|l|c|c|c|c|c|c|c|}
\hline \multirow{2}{*}{ Components } & \multicolumn{2}{|c|}{$<3$ years } & \multicolumn{2}{|c|}{$\geq 3$ years } & \multicolumn{2}{|c|}{} \\
\cline { 2 - 8 } & $\begin{array}{c}\text { Mean } \\
\text { rank }\end{array}$ & $\begin{array}{c}\text { Sum of } \\
\text { Ranks }\end{array}$ & $\begin{array}{c}\text { Mean } \\
\text { rank }\end{array}$ & $\begin{array}{c}\text { Sum of } \\
\text { Ranks }\end{array}$ & U & P & Result \\
\hline TK & 17.00 & 323.0 & 15.77 & 205.0 & 114.00 & 0.714 & No diference \\
\hline PK & 15.74 & 299.0 & 17.62 & 229.0 & 109.00 & 0.577 & No diference \\
\hline CK & 19.03 & 361.50 & 12.81 & 166.50 & 75.50 & 0.050 & No diference \\
\hline TPK & 15.84 & 301.0 & 17.46 & 227.00 & 111.00 & 0.612 & No diference \\
\hline TCK & 17.76 & 337.50 & 14.65 & 190.50 & 99.50 & 0.286 & No diference \\
\hline PCK & 16.68 & 317.00 & 16.23 & 211.00 & 120.00 & 0.892 & No diference \\
\hline TPCK & 16.66 & 316.50 & 16.27 & 211.50 & 120.500 & 0.902 & No diference \\
\hline
\end{tabular}

\section{CONCLUSION}

In the research results obtained, it can be stated that the level of ability of chemistry teachers in East Nusa Tenggara province is in the good category in general and has the highest average score on the PK component, meaning that chemistry teachers have a good understanding of how to learn and implement learning in classrooms includes everything related to planning, process, and evaluation of learning. The components that have a strong positive correlation are
PK, TPK, TCK, and TPCK which have a significant effect on the perception of TPACK for SMA chemistry teachers. Besides, based on gender and length of teaching did not have a significant effect on TPACK perception. The implication or recommendations of the results of this study can be further elaborated.

\section{ACKNOWLEDGMENT}

The author would like to thank all those who have helped write this article. 


\section{REFERENCES}

[1] A. Haider, S. Jalal, Good Teacher and Teaching Through The Lens of Students, International Journal of Research 5(7) (2018) 1395-1409.

[2] P. Agustina, Pengembangan PCK (Pedagogical Content Knowledge) Mahasiswa Calon Guru Biologi Fkip Universitas Muhammadiyah Surakarta melalui Simulasi Pembelajaran, Journal of Science Research and Learning 1(1) (2015) 1-15. DOI: https://doi.org/10.30870/jppi.v1i1.323

[3] C. Angeli, N. Valanides, Epistemological and Methodological Issues for The Consceptualization, Development, and Assessment of ICT-TPCK: Advances in Technological Pedagogical Content Knowledge (TPCK), Computers and Education 52(1) (2009) 154-168. DOI: https://doi.org/10.1016/j.compedu.2008.07.006

[4] M.L. Niess, Preparing Teachers to Teach Science and Mathematicas with Technology: Developing A Technology Pedagogical Content Knowledge, Teaching and Teacher Education 21(5) (2005) 509-523 . DOI: https://doi.org/10.1016/j.tate.2005.03.006

[5] H.J. So, B. Kim, Learning about Problem Based Learning: Student Teachers Inte grating Technology, Pedagogy and Content Knowledge, Australasian Journal of Educational Technology 25(1) (2009) 101-116. DOI: https://doi.org/10.14742/ajet.1183

[6] C.S. Chai, J.H.L. Koh, C.C. Tsai, A Review of Technological Pedagogical Content Knowledge, Educational Technology \& Society 16(2) (2013) 31-51.

[7] J.H.L. Koh, C.S. Chai, W.Y. Lim, Teacher Professional Development fo TPACK 21 CL: Effects on Teacher ICT Integration and Student Outcomes, Journal of Educational Computing Research 55(2) (2016) 172-196. DOI: https://doi.org/10.1177/0735633116656848

[8] V.C. Santos, A. Arroio, The Representational Levels: Influences and Contributions to Research in Chemical Education, Journal of Turkish Science Education 13(1) (2016) 3-18.
[9] A.H. Jhonstone, Why is Science Difficult to Learn? Things are Seldom What They Seem, Journal of Computer Assisted Learning 7(2) (1991) 75-83. DOI: https://doi.org/10.1111j.13652729.1991.tb00230 .X.

[10] J.D. Bradley, M. Brand, Stamping Out Misconceptions, Journal of Chemical Education 62(4) (1985) $318 . \quad$ DOI: https://doi.org/10.1021/ed062p318

[11] E.B. Moore, T.A. Herzog, K.K. Perkins, Interactive Simulations As Implicit Support for Guided-Inquiry, Chemistry Education Research and Practice 14 (2013) 257-268. DOI: https://doi.org/10.1039/C3RP20157K

[12] B.J. Ryan, Line Up, Line Up: Using Technology to Align and Enhance Peer Learning and Assessment in A Student Centred Foundation Organic Chemistry Module, Chemistry Education Research and Practice 14(3) (2013) 229-238.

DOI: https://doi.org/10.1039/C3RP20178C

[13] P. Mishra, M.J. Koehler, Technological Pedagogical Content Knowledge: A Framework For Teacher Knowledge, Teachers College Record 108(6) (2006) 1017-1054. DOI: https://doi.org/10.1111/j.14679620.2006.00684.X

[14] M.J. Koehler, P. Mishra, What Happens When Teachers Design Educational Technology? The Development of Technological Pedagogical Content Knowledge, Journal of Educational Computing Research 32(2) (2005) 131-152. DOI: https://doi.org/10.2190/0EW7-01WBBKHL-QDYV

[15] J. Hwee, L. Koh, Modeling pre-service teachers' technological pedagogical content knowledge (TPACK) perceptions: The influence of demographic factors and TPACK constructs, in: Proceeding of the Australasian Society for Computers in Learning in Tertiary Education's, vol. 17, The University of Tasmania, Hobart, 2011, pp. 735-746.

[16] H. Borko, J. Whitcomb, D. Liston, Wicked Problems and Other Thoughts on Issues of Technology and Teacher Learning, Journal of Teacher Education 60(1) (2009) 3-7. DOI: https://doi.org/10.1177/002248710832848 8 
[17] L. Nadolny, Z. Alaswad, D. Culver, W. Wang, Designing with Game-Based Learning: Game Mechanics From Middle School to Higher Education, Simulation \& Gaming 48(6) (2017) 814-831. DOI: https://doi.org/10.1177/1046878117736893

[18] J.H.L Koh, C.S. Chai, W.Y. Lim, Teacher Professional Development for TPACK-21CL, Journal of Educational Computing Research 55(2) (2017) 172-196. DOI:

https://doi.org/10.1177/0735633116656848

[19] M.L. Niess, R.N. Ronau, K.G. Shafer, S.O. Driskell, S.R. Harper, C. Johnston, C. Browning, S.A. Özgün-Koca, G. Kersaint, Mathematics Teacher TPACK Standards And Development Model, Contemporary Issues in Technology and Teacher Education 9(1) (2009) 4-24.

[20] C. Angeli, N. Valanides, Epistemological and Methodological Issues For The Consceptualization, Development, And Assessment of ICT-TPCK: Advances in Technological Pedagogical Content Knowledge (TPCK), Computers and Education 52(1) (2009) 154-168.

DOI: https://doi.org/10.1016/j.compedu.2008.07.006

[21] D.D. Agyei, J. Voogt, Developing Technological Pedagogical Content Knowledge in Pre-Service Mathematics Teachers Through Collaborative Design, Australasian Journal of Educational Technology 28(4) (2012) $547-564$

[22] P. Gao, S.C. Tan, L. Wang, A. Wong, D. Choy, Self Reflection and Preservice Teachers' Technologicalpedagogical Knowledge : Promoting Earlier Adoption Ofstudent-Centred Pedagogies, Australasian Journal of Educational Technology 27(6) (2011) 997-1013.

[23] J. Hwee, L. Koh, Modeling pre-service teachers' technological pedagogical content knowledge (TPACK) perceptions: The influence of demographic factors and TPACK constructs, in: Proceeding of the Australasian Society for Computers in Learning in Tertiary Education's, vol. 17, The University of Tasmania, Hobart, 2011, pp. 735-746.

[24] H. Nordin, T. Faekah, T. Ariffin, Validation of A Technological Pedagogical Content Knowledge Instrument in A Malaysian Secondary School Context, Malaysian Journal of Learning and Instruction 13(1) (2016) 1-24.

[25] A. Kaplon-Schilis, I. Lyublinskaya, Analysis of Relationship Between Five Domains of TPACK Framework: TK, PK, CK Math, CK Science, And TPACK of Pre-Service Special Education Teachers Technology, Knowledge and Learning 25(4) (2019) 25-43. DOI: https://doi.org/10.1007/s10758-019-09404-X

[26] A. Dindar, Y. Boz, D.Y. Sonmez, N.D. Celep, Development of Pre-Service Chemistry Teachers' Technological Pedagogical Content Knowledge, Chemistry Education Research and Practice 19(1) (2017) 1-30. DOI: https://doi.org/10.1039/C7RP0075D

[27]T. Altun, S. Akyıldız, Investigating Student Teachers' Technological Pedagogical Content Knowledge (TPACK) Levels Based on Some Variables, European Journal of Education 3(5) (2017) 467-485. DOI: https://doi.org/10.5281/zenodo.555996

[28]J.H.L. Koh, C.S. Chai, Examining the technological pedagogical content knowledge of singapore pre-service teachers with a large-scale survey, in: Proceedings of Australian Society for Computers in Learning in Tertiary Education Annual Conference, vol. 17, The University of Tasmania, Hobart, 2011, pp. 735-746.

[29] J. Williams, J. Ritter, S.M. Bullock, Understanding The Complexity of Becoming A Teacher Educator: Experience, Belonging, And Practice Within A Professional Learning Community, Journal of Self-Study of Teacher Education Practices 8(3) (2012) 245-260. DOI: https://doi.org/10.1080/17425964.2012.71 $\underline{9130}$ 